\title{
A comparison of satellite-altimetry and ice-thickness measurements of the Ross Ice Shelf, Antarctica
}

\author{
JONATHAN BAMBer \\ Mullard Space Science Laboratory, Department of Space and Climate Physics, University College London, \\ Holmbury St Mary, Dorking, Surrey RH5 6NT, England \\ Charles R. Bentley \\ Department of Geology and Geophysics, University of Wisconsin-Madison, Madison, WI 53706, U.S.A.
}

\begin{abstract}
ABSTR ACT. The launch of ERS-1 provides coverage, by satellite altimetry, of a large part of the Ross Ice Shelf including areas of input from Byrd Glacier and Ice Streams $\mathbf{D}$ and E. Five $35 \mathrm{~d}$ repeats of fast-delivcry data, comprising approximately 100000 height estimates, have been used to produce a Digital Elevation Model (DEM) of the Ross Ice Shelf north of $81.5^{\circ} \mathrm{S}$. Careful filtering of the altimeter data, which removed about $30 \%$ of the measurements, ensured that only valid values were used. The data were gridded to produce a DEM with a cell size of $10 \mathrm{~km}$. Repeatability of the data was assessed from an analysis of crossing points of ascending and descending tracks. The rms cross-over difference for the ice shelf was $0.94 \mathrm{~m}$. Using the five repeat tracks gave a random error of $0.30 \mathrm{~m}$ for an averaged height measurement. Regionally correlated errors in the orbit and geoid add a systematic long wavelength bias of approximately $2 \mathrm{~m}$ to the final elevation estimate. Two of the latest geoid models, OSU91-A and JGMI, were compared with the available in situ data and hydrostatic models based on ice and water densities.

The altimetry was compared with ice-thickness data from Ross Icc Shelf Geophysical and Glaciological Survey (RIGGS) stations and Scott Polar Research Institute radio-echo-sounding surveys undertaken in the 1970s. Differences between the DEM and heights calculated from ice thicknesses and a standard density depth equation lie, in general, within the combined measurement errors. There are, however, several areas where this is not the case. Prominent north-south stripes of different ice thickness shown on a RIGGS map apparently do not exist. Low elevations are associated with high-density ice draining from East Antarctic outlet glaciers. The grounding line of Ice Strcams D and E and an ice plain behind it are clearly demarcated by the break in surface slope. Grounded ice north of Steershead is also observed.
\end{abstract}

\section{INTRODUCTION}

The Ross Ice Shelf is one of the most studied regions of Antarctica with a comprehensive network of strain-rate, surface-velocity, mass-balance, $10 \mathrm{~m}$ temperature and icethickness measurements made during the 1970s (Bentley, 1984). Until recently, however, it has remained beyond the latitudinal limit of satcllite-altimeter missions. The launch of ERS-1 in July 1991 has enabled us to map surface elevation with sub-meter precision up to a latitude of $81.5^{\circ} \mathrm{S}$, thus covering areas of inflow from Byrd Glacier and Ice Streams D and E, complementing the more thoroughly investigated Ice Streams A, B and C (e.g. Shabtaie and Bentley, 1987). For example, the input mass flux from Ice Stream E is second only to Ice Stream B and represents about $20 \%$ of the total inflow (MacAycal and Thomas, 1986; Shabtaie and Bentley, 1987), yet its grounding line is poorly known, and ice-thickness data are relatively sparse in this region (Bentley and others, 1979). The altimetcr data can, howcver, be used to provide information on both of these parameters (e.g. Partington and others, 1987).

Ice thickness can be inverted to provide surface elevation (or vice versa), assuming that the mean ice and water densities are known and that the ice is in hydrostatic equilibrium. Differences between the altimeter-derived heights and those derived from the radioecho-sounding (RES) data indicate a failure of one or more of the assumptions. Possible causes include grounding, ice-density variations and a change in surfacc elevation in the 15 years between measurements. Mean ice density may vary due to differences in densification rate of the firn layer, thickening due to compression in flow or the freeze-on of marine ice. 


\section{DATA ANALYSIS AND REDUCTION}

\section{Altimeter data}

ERS-1 altimeter data are distributed in two forms. The first, distributed as wave-form data, comprise a comprehensive data set with corrections, quality flags and wave forms at the full sampling rate of $20 \mathrm{~Hz} .335 \mathrm{~m}$ along-track . A complex ground-processing procedure, requiring the input of a number of auxiliary data sets, is used in producing the wave-form product and at present only limited amounts of these data are available. The second type is known as the fast delivery (FD) data set and is a summary product, with a reduced spatial resolution of $6.7 \mathrm{~km}(1 \mathrm{~Hz})$ along-track. No wave forms are included and a relatively limited range of other parameters is provided. This product requires minimal ground processing and is, therefore, available relatively soon after acquisition.

In this study, five $35 \mathrm{~d}$ repcat cycles of FD data were used, comprising approximately 100000 measurements of surface clevation over the ice shelf and surrounding region. These data were improved with the use of ESA precise orbits, which are available approximately 3-6 months after acquisition (ESA, 1992). They are calculated from a gravity model tailored to the ERS-1 mission.

In the absence of wave forms, it is necessary to carry out careful filtering to remove erroneous data, and the procedures used to do this have been described elsewhere (Bamber, 1994a). After filtcring, a DLM with $10 \mathrm{~km}$ grid spacing was produced in a polar stereographic projection with its origin at the South Pole, and a standard parallel of $71^{\circ} \mathrm{S}$. Slope corrections were applied by the re-location method (Brenner and others, 1983), using a procedure described elsewhere (Bamber, 1994a). The data coverage after filtering is indicated in Figure 1 and the resultant elevation map (with $2 \mathrm{~m}$ contours) is shown in Figure 2a.

\section{Error sources}

The errors in the satellite-altimeter estimate of elevation comprise two components:

$$
E=E_{\text {random }}+E_{\text {bias }} .
$$

\section{Random errors}

The orbit error is quoted as being better than $50 \mathrm{~cm}$ (ESA, 1992); however, it is likely to be worse than this in the Antarctic due to the paucity of tracking stations in the Southern Hemisphcre. Atmospheric corrections for the fast-delivery data are coarse, predicted values. However, the error in using these is no more than $30 \mathrm{~cm}$ (Cudlip and others, 1994). There are both random and systematic errors due to not recalculating the range estimate, a proccss known as retracking (Martin and others, 1983), which can only be carried out on wave forms. The magnitude of these errors was assessed by calculating the mean and standard deviation of the retracking correction obtained from a small data set of wave forms over the Ross Ice Shelf. A thrcshold-retracking technique (Bamber, 1994b) was used and the mean correction was found to be $-0.18 \pm 0.26 \mathrm{~m}$ at the $95 \%$ confidence limit. No tide correction was applied and tides are about $1-2 \mathrm{~m}$ in magnitude (Williams and Robinson, 1980). Their effect, however, is averaged out by the use of multiple orbits $(\approx 2500$ ) which have no temporal corrclation with the tidal periods.

The combined random errors can be determined from a comparison of crossing points of descending and ascending orbits. The standard deviation of 4303 cross-

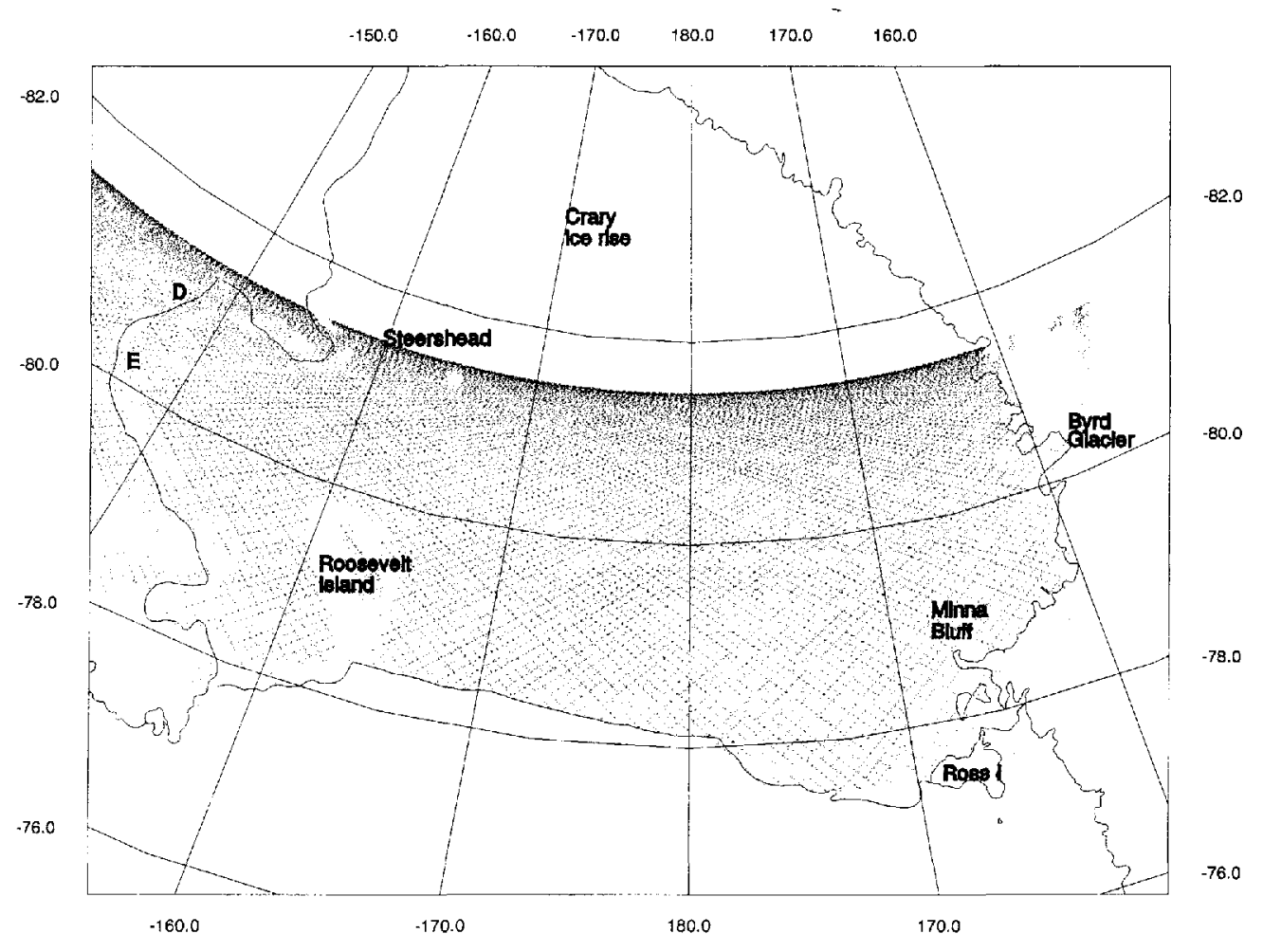

Fig. 1. Coverage of altimeter-height measurements, after remozal of poor data, for one of the five $35 d$ repeats used. 

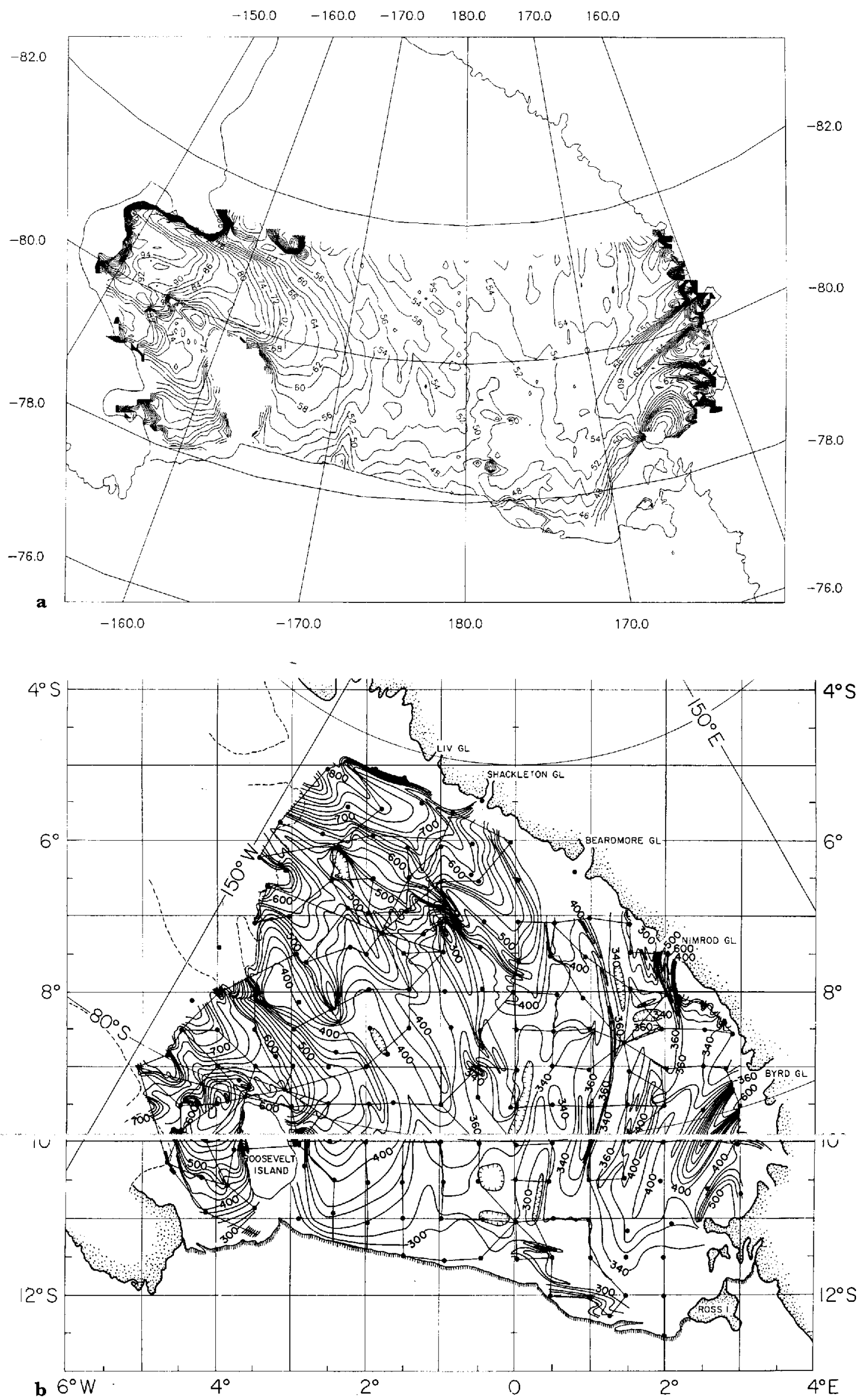

Fig. 2. a. Map of surface elevations, from radar altimetry, for Ross Ice Shelf relatize to the OSU91-A geoid. Maximum elevation plotted is $120 \mathrm{~m}$. The $2 \mathrm{~m}$ contour interval used is equivalent to about $19 \mathrm{~m}$ in ice thickness $(\mathrm{cf} .20 \mathrm{~m}$ contours in Figure 2b). b. Map of ice thicknesses (after Bentley and others, 1979), derived from RIGGS airborne and station RES dala. 
overs for one of the $35 \mathrm{~d}$ repeats was $1.56 \mathrm{~m}$ over the ice shelf and surrounding grounded ice regions. This figure was reduced to $0.94 \mathrm{~m}$ for the ice-shelf region only. If this is the random component of the height error on two measurements on the ice shelf, then combining five repeat tracks reduces it to $0.30 \mathrm{~m}$ for a single height estimate.

\section{Biases}

There are two geographically correlated biases. The first is due to a spatially invariant orbit error that arises from a poor knowledge of the local gravity field (Tapley and Rosborough, 1985). Based on a comparison between two geopotential models, the rms crror in the orbit due to this source was estimated as $1.50 \mathrm{~m}$. The second bias is due to errors in the geopotential model used to convert from altimeter-derived heights relative to the ellipsoid to heights relative to the geoid. In this study, two of the most recent geopotential models were considered, the OSL91-A and JGM1 (Rapp and others, 1991). They were compared with the available in situ measurements of mean sea level and with each other.

There are only nine locations where heights relative to mean sea level and the ellipsoid were determined accurately enough to compare with the models (Shabtaie and Bentley, 1987). The requirement on repcatability of these height measurements was to $<5 \mathrm{~m}$, and this is therefore likely to represent the upper limit on their error. Bearing this in mind and taking into account that, in general, mean sea level is taken to be $1.5 \mathrm{~m}$ below the gcoid in the Antarctic (personal communication from R. H. Rapp, 1993), the differences between the modelled and measured values for the OSL $91-A$ and JGM1 models were $3.8 \pm 2.8 \mathrm{~m}$ and $-3.7 \pm 3.1 \mathrm{~m}$, respectively, where the errors are $1 \sigma$. For the Ross Ice Shelf embayment, the two models agree to better than $1 \mathrm{~m}$ up to $70^{\circ}$ (the limit of JGM1), and for this study we chose the OSU geoid as it is complete to $360^{\circ}$, thus providing undulations on a $50 \mathrm{~km}$ wavelength.

The OSU model has been compared with GPS/ levelling data and with Geosat sea-surface topography, and the errors have been estimated to range from $\pm 0.26 \mathrm{~m}$ over the ocean to $\pm 2 \mathrm{~m}$ over land areas with no surfacc gravity data (Rapp and others, 1991). Although gravity data exist for the Ross Ice Shelf embayment, it scems unlikely that they were included in the terrestrial data used in either of the geoid models and the error in the geoid is, therefore, likely to be on the order of $\pm 2 \mathrm{~m}$. This is about half the difference between the measured and modelled values, discussed earlier. It is possible, however, that part of the difference may be due to biases in the in situ data. It will be shown later that good agreement is obtained between the theoretically derived equation relating surface elevation to ice thickness and the measured relationship using the OSU91-A model.

\section{Ice-thickness data}

Two data sets were used in this investigation, the tabulated values of ice thickness for each Ross Ice Shelf Gcophysical and Glaciological Survey (RIGGS) station (Greischar and others, 1992) and the Scott Polar Research Institute (SPRI) radio-echo soundings made during the 1970s (Drewry, 1983). The RIGGS airborne surveys represent the most comprehensive data set over the Ross Icc Shelf, but werc not available in digital form, and therefore could not be used for a quantitative analysis in this study. However, an ice-thickness map produced from those data (Bentley and others, 1979) is reproduced here (Fig. 2b).

The location of SPRI flight lines and RIGGS stations is indicated in Figure 3. RIGGS ice thicknesses have an accuracy of about $10 \mathrm{~m}$ (Greischar and others, 1992). Stations with a location accuracy of worse than $3 \mathrm{~km}$ were discardcd (Fig. 3). The accuracy of the SPRI data was assessed from the crossing-point differences. These had a standard deviation of $14.8 \mathrm{~m}$ with some differences in excess of $30 \mathrm{~m}$. As can be seen from Figure 3, the SPRI airborne coverage is relatively sparse. The track spacing is about $50 \mathrm{~km}$. Features running north-south with a wavelength less than approximately $100 \mathrm{~km}$ will not be detected in the icc-thickness data used. The amount of short-wavelength information in this data set is less than that indicated by the ice-thickness map produced from the airborne RIGGS data (Fig. 2b). The SPRI data were used, however, as they allow a quantitative estimate of the surface-elevation differences to be made, as described in the next section.

\section{Comparison of ice thicknesses and surface elevations}

Assuming that the floating ice is in hydrostatic equilibrium, the surface elevation can be derived from the following equation:

$$
e=\frac{\left(\rho_{\mathrm{w}}-\rho_{\mathrm{i}}\right)}{\rho_{\mathrm{w}}} Z+\frac{\rho_{\mathrm{i}}}{\rho_{\mathrm{w}}} \delta
$$

where $\delta=Z\left(1-\bar{\rho}_{\mathrm{i}} / \rho_{\mathrm{i}}\right), Z$ is ice thickness, $\rho_{\mathrm{i}}$ and $\rho_{\mathrm{w}}$ are the densitics of ice and water, respectively, and $\bar{\rho}_{\mathrm{i}}$ is the vertically averaged ice density (Shabtaie and Bentley, 1982). If it is also assumed that $\delta$ is constant over the ice shelf, then Equation (1) is linear. The RIGGS station ice thicknesses were used alone in a linear regression against

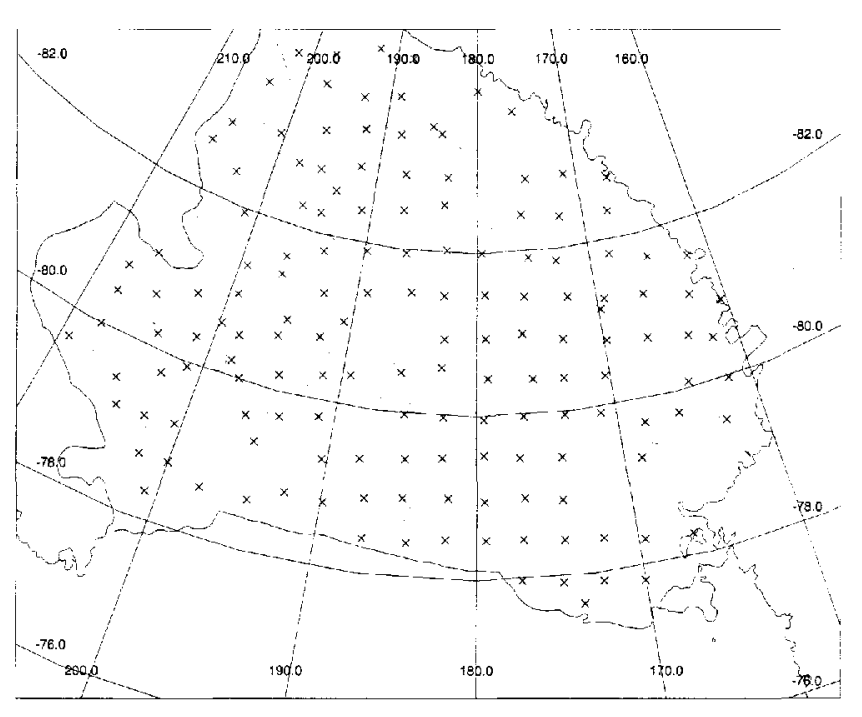

Fig. 3. Location of RIGGS stations (crosses) and radioecho-sounding flight lines used in the analysis. 
surface elevation, as these data have a higher accuracy compared to the airborne SPRI data and are less prone to interpretational problems. Points that were known to be grounded were not included (Greischar and others, 1992). Bilinear interpolation was used to find the surface elevation at cach RIGGS station from the gridded DEM. A linear fit to the data (Fig. 4), by least squares, yielded:

$$
e=(0.104 \pm 0.004) Z+15.5 \pm 2.6
$$

where the errors are expressed at the $95 \%$ confidence limit and the correlation coefficient was 0.91 . The fit to the data is shown in Figure 4 by the solid line. Equation (2) agres better with the relationship dcrived using a density for solid ice $\left(917 \mathrm{~kg} \mathrm{~m}^{-3}\right.$ ) (Shabtaie and Bentley, 1987) than with one derived from the measured density in an ice core at Little America (Greischar and others, 1992). The mean ice-shelf density below the firn layer is surely greater than $910 \mathrm{~kg} \mathrm{~m}^{-3}$, the value assumed by Greischar and others (1992). However, it is possible that errors in the short-wavelength components of the geoid (<length of the ice shelf), of a metre or two, could be responsible for part of the difference. Long-wavelength errors ( $>$ ice-shelf dimension) would simply produce a bias which would affect $\delta$ only. For a $200 \mathrm{~m}$ thick and $700 \mathrm{~m}$ thick column of ice, the differences in surface elevation between the equation derived by Shabtaic and Bentley (1987) and that of Greischar and others (1992) are $1.2 \mathrm{~m}$ and $-3.05 \mathrm{~m}$, respectively, which are within the random crror.

Using Equation (2), all the ice-thickness data were converted to surface elevations and interpolated into a second DEM with the same grid spacing and coordinate

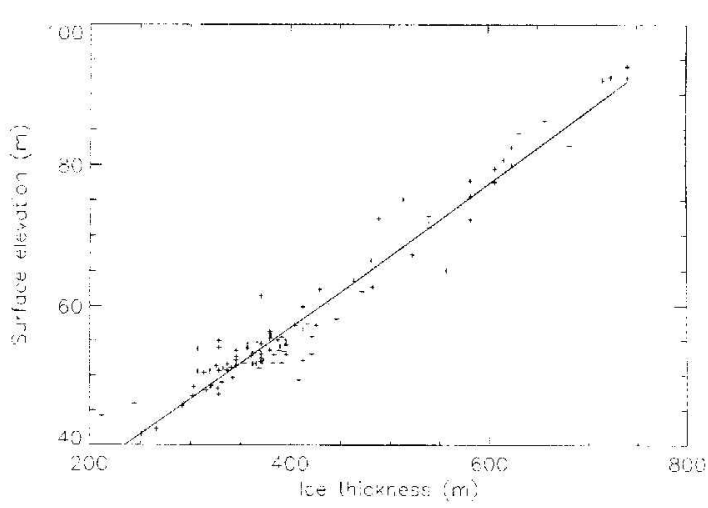

Fig. 4. Least-squares fit to the elevations (interpolated from the ERS-1 alimetry) versus the ice thicknesses for the 103 RIGGS stations within the coverage of the satellite, excluding areas known to be grounded.

system as the ERS-1 altimeter DEM. A difference map was produced by subtracting the RES-derived elevations from the altimeter values. A grey-scale contour plot of the differences is shown in Figure 5. Positive differences are hatched. Combining the errors in ice thickness and surface elevation $\left(E_{\text {random }}+E_{\text {bias }}\right)$ gives an rms error of $\pm 4 \mathrm{~m}$ for the differences in Figure 5 .

\section{DISCUSSION}

The main features in Figure $2 \mathrm{a}$ and $\mathrm{b}$ are in broad agreement. Along the eastern boundary of the ice shelf, the lobes of thick ice emanating from Ice Streams D and

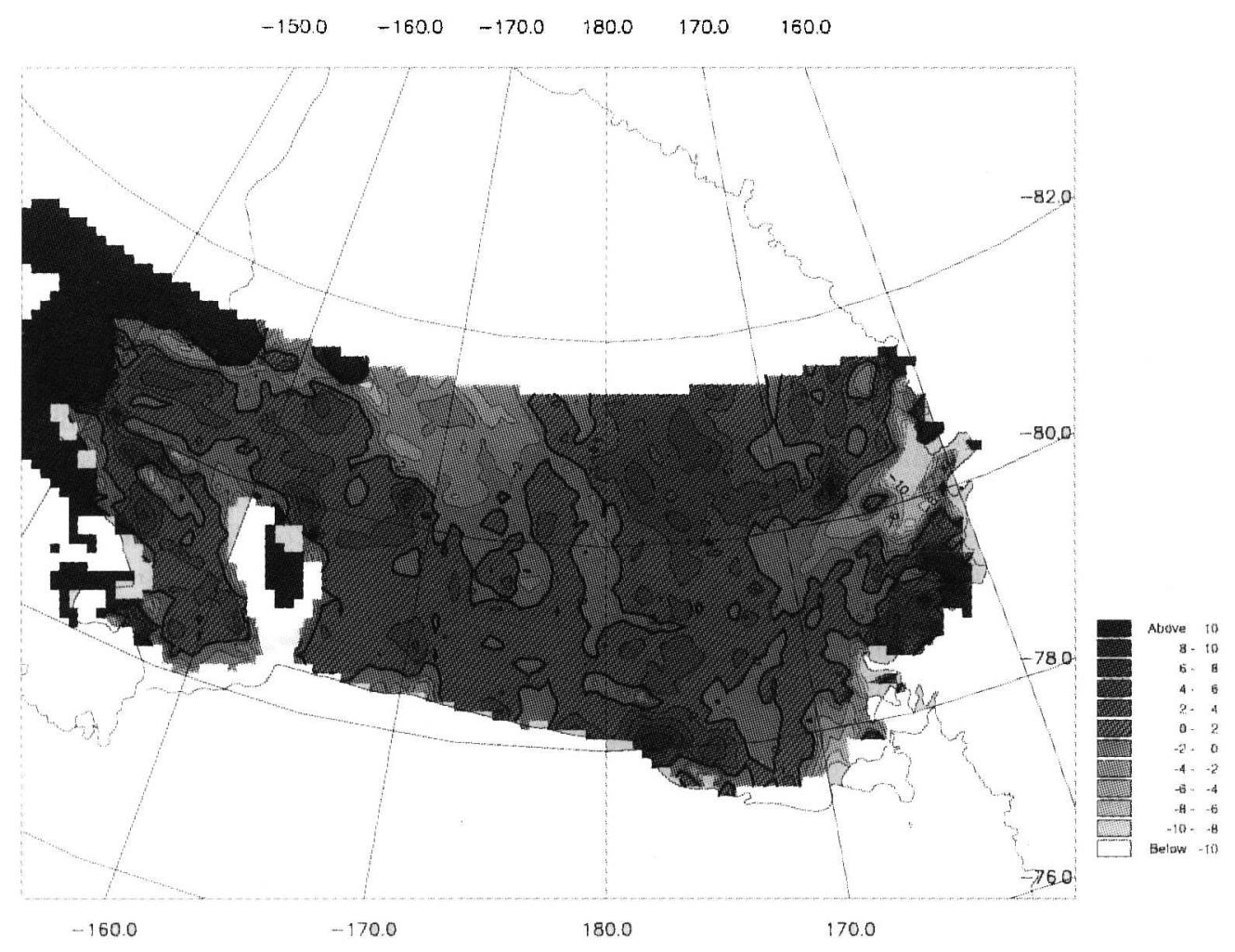

Fig. 5. Map of altimeter-derived elevations minus elevations derived from ice thicknesses by using an equation for hydrostatic equilibrium (Equation (2)). The contour interwal used was $2 \mathrm{~m}$. Positive differences are halched. Unshaded regions equate to areas where no data were available. 
$\mathrm{E}\left(80^{\circ}-81^{\circ} \mathrm{S}, 150^{\circ} \mathrm{W}\right)$ can be seen clearly flowing around Roosevelt Island $\left(79^{\circ} \mathrm{S}, 163^{\circ} \mathrm{W}\right)$. In between them, just southeast of Roosevele Island, is a low, thin spot that presumably is a "backwater" associated with flow around a stationary boundary (Massey, 1979). The northern boundary of the ice rise informally called "Steershead" $\left(81.5^{\circ} \mathrm{S}, 163^{\circ} \mathrm{W}\right)$, associated with the Steershead Crevasses, is well delineated on the elevation map and shows good accord in its appearance with the maps of Shabtaic and Bentley (1987). Jezek (1980) and Bentley and Jezek (1981), from a study of bottom crevasses, suggested that several other previously unrccognized ice rises exist. Two of them would be within our coverage: one just east of Steershead at $160^{\circ} \mathrm{W}$ and the other at about $80.3^{\circ} \mathrm{S}$, $.172^{\circ} \mathrm{W}$. There is no sign of either.

Obvious features along the western margin of the ice shelf that are common to the two maps are the thick lobcs in front of major outlet glaciers, most prominently Byrd Glacier $\left(80.2^{\circ} \mathrm{S}, 160^{\circ} \mathrm{F}\right)$ and Mulock Glacier $\left(79^{\circ} \mathrm{S}\right.$, $\left.162^{\circ} \mathrm{E}\right)$, and the thick ice dammed behind Minna Bluff $\left(78.7^{\circ} \mathrm{S}, 157^{\circ} \mathrm{E}\right)$. The downstream end of a lobe from Nimrod Glacier, most of which is south of the satellitc covcrage but which shows prominently on the icethickness map, appears at $81.5^{\circ} \mathrm{S}, 165^{\circ} \mathrm{E}$.

Some more subtlc fcatures are also reproduced in the central ice shelf the ridge that trends southeastward from around $80^{\circ} \mathrm{S}, 177^{\circ} \mathrm{W}$ and the low spots ncar $79^{\circ} \mathrm{S}$, $178^{\circ} \mathrm{L}$ and $78^{\circ} \mathrm{S}, 178^{\circ} \mathrm{E}$. These low spots were attributed by Jezek (1980) to break-offs and downstream movement of thin ice formed in the lee of Crary Ice Risc (south of the satellite limit). The more northerly low spot, a known rift in the ice shelf (Bentley and others, 1979, fig. 3), is sharp cnough and closcly cnough delineated on both maps that its displacement can be approximately measured. This displaccment, about $12 \mathrm{~km}$, is in reasonable agreement with the measured ice speed $954 \mathrm{ma}^{-1}$; Thomas and others, 1984) and the time interval of 15 years January 1977-January 1992). The "anomaly" at a grid position of $11.4^{\circ} \mathrm{S}, 0.5^{\circ} \mathrm{E}$ (Fig. 2b) is also prominent in the surface elevations and is, clearly, a real feature. It appears as a negative difference in Figure 5 because there were no SPRI RES data sufficiently close to it and, consequently, it was not resolved with the data used.

In the west-central part of the ice shelf there is a significant disagreement between the maps. The surface elevations show no sign of the striking ridge trough system shown on the ice-thickness map running parallel to flow across much of the ice shelf betwecn $180^{\circ} \mathrm{E}$ and the Byrd Glacicr flow bulge. We now believe that these ridges and troughs may not represent real variations in ice thickncss but rather cchocs from a reflector within the ice a few tens of metres above its base (Bentley, 1981). These internal echoes are stronger than the basal echocs; both can be seen on the high-gain SPRI radio-echograms but only one echo appears on the RIGGS records that were used by Bentley and others (1979) to construct their map. We suspect, therefore, that the bands of indicated thinner ice on the map really represent bands of ice, stretched out along flow, that contain the internal reflector. We note also that the western part of the ice shelf displays pronounced bands of differing basal characteristics revealed by radio-echo sounding and attributed variously to bottom melting and freezing (Neal, 1979), and different propertics from different source regions in the Transantarctic Mountains (Bentley, 1981).

That appears to be the only falsification of the icethickness map by the elevation map. However, there are some new features of interest on the elevation map. Around $78^{\circ} \mathrm{S}, 170^{\circ} \mathrm{E}$, the new map shows a zonc of strong gradient in elevation (and, presumably, ice thickness there is almost no radio-echo-sounding information in this region) between the main body of Ross Icc Shclf and McMurdo Ice Shelf south of Ross Island. This gradient extends surprisingly far out into the ice shelf. The isopachs are not parallel to flow (Thomas and others, 1984), so there must be rapid thinning along the flowlines. The flow is neither divergent nor spatially accelerating in the direction of thinning, so the thinning must reflect rapid basal melting, perhaps produced by oceanic flow southward beneath the ice shelf and around Ross Island into McMurdo Sound, as suggested by Lewis and Perkin (1985). Contrary to this idca, however, is the lack of any warm source water in this region along the Ross Ice Shelf front (Pillsbury and Jacobs, 1985).

Another new feature is the valley along $171^{\circ} \mathrm{W}$ north of $79.5^{\circ} \mathrm{S}$ that deepens all the way to the ice front. It lies entirely between the two nearest RIGGS flight lines, so could not show on the ice-thickness map, although there is a suggestion of it farther south (Fig. 2b) around grid $9.5^{\circ} \mathrm{S}, 2^{\circ} \mathrm{W}$. This valley begins about $70 \mathrm{~km}$ to the east of the northern end of the broad valley that curves northwestward from just west of Steershead across $80^{\circ} \mathrm{S}$ at $173^{\circ} \mathrm{W}$. It lies directly down-flow from Stcershead itself, according to both the velocity vectors (Thomas and others, 1984) and flow stripes in the ice (Shabtaie and Bentley, 1987). The continuity of the flow stripes proves that the new-found feature was not formed by an eastward displacement of the broad valley, a possibility that is suggested by the elevation map, yet the feature itself does not extend continuously back to Steershead. We suggest that this is a break-off of thin ice from the lee of Steershead, according to the model of Jezek (1980) and Bentley and Jezck (1981), already mentioned.

Perhaps the most useful feature of the new map is the delineation of the grounding lines of Ice Streams 1 and $\mathrm{E}$, which show strikingly on an expanded-scale map (Fig. 6 , heavy solid line). The position of the grounding line, cstimated from the break in slope, is in good agrecment with that mapped by Scambos and Bindschadler (1991), although the altimeter version is smoother and less complcx duc to the gridding and contouring of the data. The position of the grounding line near $80.1 \% \mathrm{~S}$, $150^{\circ} \mathrm{W}$ was confirmed by Jacobel and Bindschadler (1993) using surface-based radio-cho-sounding and tiltmeter measurements, and is in excellent agreement with the altimeter cstimatc. Not only is the grounding line marked, by an abrupt change in the surface slope, but an ice plain is also clearly indicated by surface flattening and even reversals in slope, as on the ice plain of Ice Stream B (Shabtaje and Bentley, 1987). This is also apparent in the imagery of this area Jacobel and Bindschadler, 1993).

The difference map (Fig. 5; can be cxpected to show; principally, four things: grounded ice, secular changes, spatial variations in the mean density of the ice shclf and errors in one or the other of the DEMs. We believe errors are few and mostly small in extent. The only large feature 
on the map that we believe probably results from error is the broad negative anomaly, marginally significant in amplitude, that lies between Steershead and $180^{\circ} \mathrm{E}$. There is no reason to suspect abnomally high densities here - neither the snow-accumulation rates nor the strain rates are anomalous (Thomas and others, 1984) so we suspect that the cause is cither orbit error or an inaccuracy in the geoid model.

Many small anomalies appear between Rooseselt Island and Ice Stream D and also on the southwest side of Roosevelt Island. These we attribute principally to imperfect positioning and lack of resolution, in the icethickness DEM, of the small-scale, steep-sided features that characterize these areas. However, it is also likely that changes havc occurred with time in these regions.

There are three areas, where there is adcquatc RES data, that show significant positive differences that may indicate grounding. The first lies at $80.3^{\circ} \mathrm{S}, 168^{\circ} \mathrm{W}$. The second at $80.0^{\circ} \mathrm{S}, 163^{\circ} \mathrm{W}$ and the third at $80.3^{\circ} \mathrm{S}, 168^{\circ} \mathrm{E}$. However, for the latter two, the differences are about $6 \mathrm{~m}$, which is only just above the error margin.

Over the major part of the ice shclf, the differences shown in Figure 5 lie well within the $\pm 4 \mathrm{~m}$ margin of error. This indicates a general lack of lateral variability in mean ice density. An obvious exception to this is the region of large negative differences $>10 \mathrm{~m}$ ) along the outflow from Byrd Glacier, which is duc-to a rapid increase of density with depth in the near-surface firn, as shown by a seismic short-refraction profile Kirchner and Bentley, 1990). A $10 \mathrm{~m}$ lower surface height, compared with the $15.5 \mathrm{~m}$ intercept term in Equation (2) (which represents the integrated height of the air column in the firn shows that the near-surface densities should be about $65 \%$ closer to the solid-ice density than the average for the firn layers across the ice shelf. This is approximately what the short-rcfraction profile shows (Kirchner and Bentley, 1990, fig. 23). Similar anomalies are associated with Mulock and Skelton Glacicrs, presumably from similar stress-induced high derssities.

\section{CONCLUSIONS}

In this initial study, we have shown that the fast-delivery altimeter data from ERS-1 give new insights into the morphology of the Ross Ice Shelf. Deviations from the hydrostatic model rclating ice thickness and surface elevation have been shown to provide information on areas of grounding and changes in mean ice density. The use of altimeter wave-form data and the full complement of radio-ccho-sounding data, including the R IGGS flight lines, will allow a more detailed study to be undertaken in the future.

\section{AGKNOWLEDGEMENTS}

'The authors thank R. H. Rapp for his help with the geoid crrors and analysis, and D. Vaughan for providing the SPRI RES data. Funding for J.L.B. was through U.K.

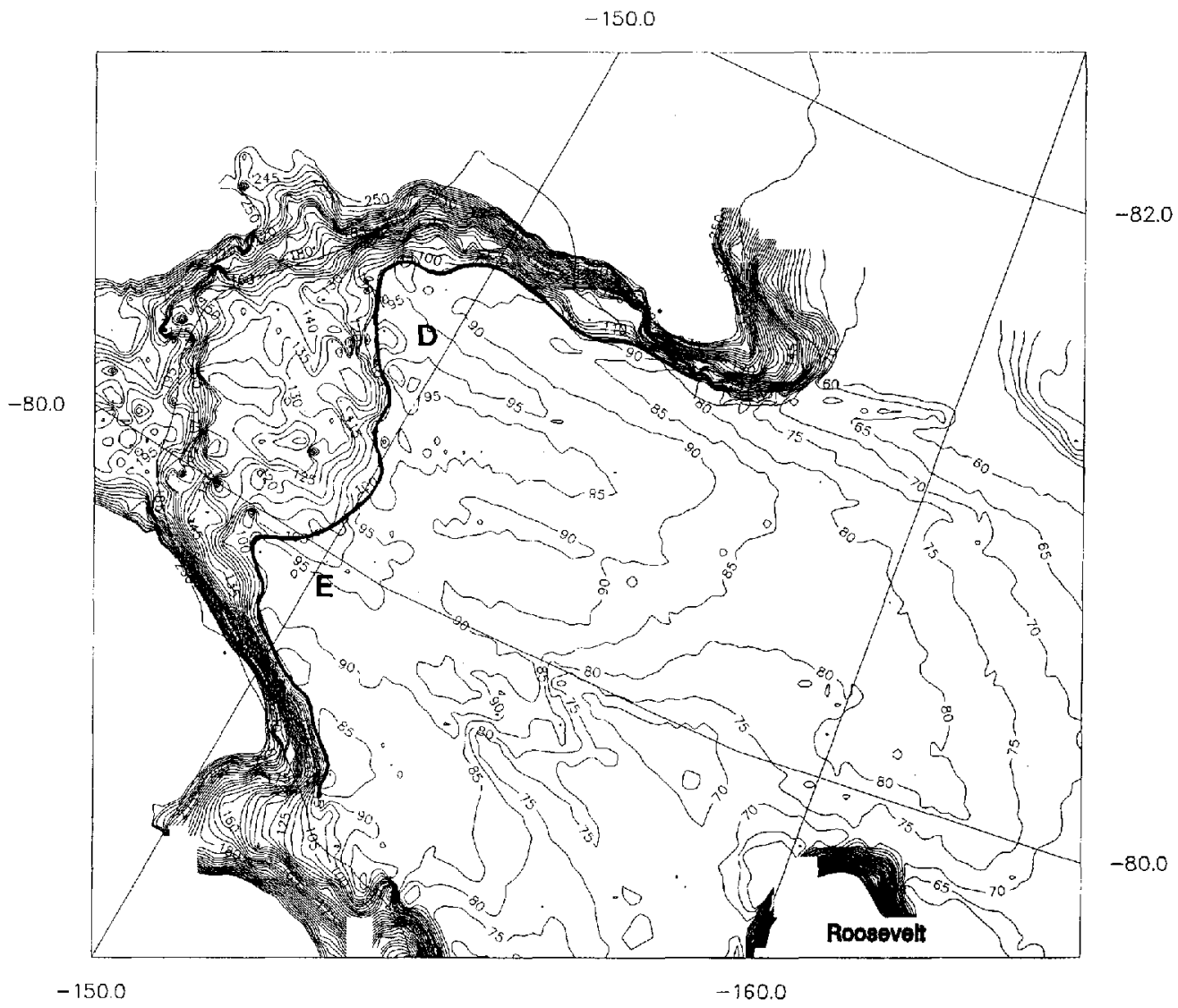

Fig. 6. Map of surface elevations on the ice plain of Ice Streams $D$ and E, and the neighbouring part of the ice shelf. Elerations aboze $250 \mathrm{~m}$ are not plotled. The approximate location of the grounding line, from the break in slope, is shown as a heary solid line. 
Natural Fuvironment Research Council grant GR3/7836. 'I'his is contribution No. 550 of the Gcophysical and Polar Research Center, Lniversity of Wisconsin-Madison. The ERS-1 data were supplicd by ESA.

\section{REFERENCES}

Bamber. J. L. 1994a. A digital clevation model of the Antarctic ice sheet drived from ERS-1 allineter data and comparison with terrestrial measurements. Ann. Glacing. 20 isce paper in this volume).

Bamber, J. L. 1994b. Ice sheet altimeter processing scherne. Ihl. J. Rem. Sens. 15 1, 925938.

Bcntley, C.R. 1981. Variations in ralley glacicr activity in the Transantarctic Mountains as indicated by associated flow bands in the Ross Ice Shelf. International Association of Hydrolosical Scientes Publication 131 Sea lect. ice and dimatic change), 247251.

Benlley, C. R. 1984. The Ross Ice Shelf Geophysical and Glaciological Surey RIGGS): introduction and suminary of measurements porformed. Antowt. Res. Ser., 42, 120.

Bontley, C. R, and K. C. Jezek. 1981. RISS, RISP and RIGGS postIGY glatiological investigations of the Ross Icc Shelf in the U.S. programme. 7. Roy. Soc. Veic Zeatand, 11; $;$, 355-372.

Bentley, C. R.. J. W. Clomgh, K. C. Jezek and S. Shabtaie. 1979. Icethickiness patterns and the dy namics of the Ross loc Shelf, Antarrica. J. Gitatiol, 2490 , 287-294.

Bremer. A. C., R. A. Bindschadier, R. H. Thomas and H.J. Zwally. 1983. Slope-induced crors in radar altimetry over continental ice shects. J. Gophts. Res., 88(C3), 16171623.

Cudlip. 11. and 7 thers. 1994. Corrections for altimeter low-level procensing at the EODC. Im. J. Rem. Sens., 154/, 889914.

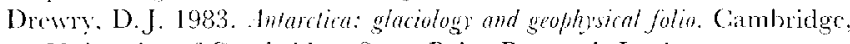
Lniversity of Cambridge. Scott Polar Research Institute.

Luropcan Spar Agency. 1992. ERS-1 System. ESA SP-1146.

Greischar, L. L.. C. R. Bentey and I., R. Whiting. 1992. An analyis of gravity measurements on the Ross Ice Shelf, Antarctica. Antare. Res. Se. 57. 105150

Jacobrl, R. W. and R.A. Bindschadler. 1993. Radar studies at the moutles oficestreams 1) and E, Antartica. Ann. Glaciol., 17, 262-268.

Jezck. K. C. 1980. Radar investigations of the Ross Ice Sletl. Antaretica. Ph.D. thesis, Lniversity of Wisconsin-Madison

Kinchuce, J.l: and C.R. Bentley. 1990. RIGGS III: seismic short- refraction studies using an analytical curve-fitting technicue. Antart. Res. Ser., 42, $109 \cdots 126$.

Lewis, E. L. and R.G. Perkin 1985. The winter ocenography of McMurdo Sound, Antarcica. Antard. Re's. Ser. 43. 145165.

MacAyeal, D. R. and R. I1. Thomas. 1986. The eflects of basal melting on the present flow of the Ross ler Shelf, Antirctica. $f$. Gitatel. $32110,72-86$.

Martin, T. Y.. H.J. Zwally, A. C. Brenner and R. A. Bindschadler. 1983. Analysis and retracking of continental ire sheet radar altimeter wavcfurms. 7. Geophs. Re, 88<C3, 1608-1616.

Massey, B.S. 1979. Wechanics of fludts. Fowth edition. New York. Vin Nostrand Rienhold Company

Neal, C.S. 1979. Dynamics of the Ross Ice Shelf as revealed by radioclos sounding. j. Glaciol. 2490 295307.

Partington, K. C.. W. Cudlip. N. F. McIntyre and S. King-Hele. 1987. Mapping of Amery lec Shelf, Antaretica, surface features by satellite alimetry. Am. Glaciol, 9, 183-188.

Pillsbury, R.D. and S.S. Jacobs. 1985. Preliminary observations from long-term current meter moorings near the Ross Ice Shelf. Antarcica. Antard. Res. Ser, 43,87-107.

Rapp, R. H., Y. M. Wang and N. K. Parlis, 1991. The Ohio State 1991

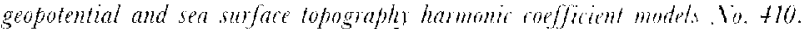
Columbus, OH, Department of Grodetic Science and Surveying. Ohio State Lniversity.

Scambos, T. 1. and R. A. Bindschadler. 1991. Feature maps of ice strcams (C, 1), and E, W'est Antarctical tutart f. [.S. 26.5. 312. 314 .

Shabtaic, S. and C.R. Bentley. 1982. Tabular irebergs: implications from geophrsical studies of ire shclyes. 7. Glaciol. 28 100.413-430.

Shabtaic, S. and C.R. Bentey. 1987. West Antarctic ice streams draining into the Ross Ice Shelf: conliguration and mass balance. $\hat{j}$. Geophys, Res., 92 B2:, 1311-1336.

Tapley, B. D. and G. W. Rosborough. 1985. Geographically correlated orbit error and its effect on satellite altimetry missions. f. Geophrs. Res. $90(\mathrm{C6} ;, 11,81711,831$.

Thomas. R. H.. D. R. Maciveal, D. H. Eilers and D. R. Gaylord. 1984 Glaciological studies on the Ross Ice Sludi, Antarctica, 1973-1978. Anart. Res. Ser, 42, 21-53.

Williams, R. T. and L. S. Rubinson. 1980. The orean ticle in rhe southem Ross Sca. J. Gephes. Res., 85 ( 11$), 6689-6696$.

The accuracy of references in the text and in this list is the responsibility of the authors, to whom queries should be addressed. 